\title{
Confusion in the Taxonomy of a Nitrogen-fixing Bacterium Currently Classified as Mycobacterium flavum 301
}

\author{
By D. R. BIGGINS* and J. R. POSTGATE \\ A.R.C. Unit of Nitrogen Fixation, University of Sussex, Brighton, BNI $9 Q J$, Sussex \\ (Accepted for publication 18 December 1970) \\ INTRODUCTION
}

Federov \& Kalininskaya (I96 I $a$ ) described an aerobic, allegedly Gram-negative, nitrogen-fixing bacterium isolated from turf-podzol soils and classified it as Mycobacterium flavum $30 \mathrm{I}$ according to Krasil'nikov's (1959) scheme. They pointed out that it would not be so classified according to Bergey's scheme (Breed, Murray \& Smith, 1957; Buchanan, Holt \& Lessel, 1966). Confusion concerning the position of mycobacteria exists, and we report here some comments and experiments relevant to the taxonomy of $M$. flavum 30r. A culture is lodged in the National Collection of Industrial Bacteria (NCIB), strain number 10,071. We have reported on the nitrogenfixing system in this organism (Biggins \& Postgate, 1969).

\section{LITERATURE AND EXPERIMENTAL}

The name 'Mycobacterium flavum'

Krasil'nikov used the name Mycobacterium flavum in a very broad sense. He distinguished several subspecies and varieties which in Bergey's scheme are placed in genera including Arthrobacter, Bacillus, Corynebacterium, Nocardia and Ramibacterium. But the name Mycobacterium flavum was first used by Jensen (I934) for an organism which had been named Microbacterium flavum by Orla-Jensen (I9I9); see Bergey's Manual, sixth edition (Breed, Murray \& Hitchins, 1948). The latter name became generally accepted; Jensen's name was omitted from the seventh edition of Bergey's Manual (Breed et al. 1957).

However, the name Mycobacterium flavum as used by Jensen (1934) is validly published and legitimate (Buchanan, Holt \& Lessel, I966). Therefore, according to the International Code of Nomenclature, any Mycobacterium flavum which appeared after Jensen (1934), might be expected to follow the description he gave for this name. Krasil'nikov's description of Mycobacterium flavum is based on Mycobacterium flavum Jensen, 1934 and 'Mycobacterium flavum Orla-Jensen, 1919'. (The latter may well be an error in transliteration and may refer actually to Orla-Jensen's Microbacterium flavum.) It seemed reasonable, therefore, to expect Mycobacterium flavum $30 \mathrm{I}$ to resemble Microbacterium flavum; we therefore sought a culture of Microbacterium flavum conforming to the description of Orla-Jensen (1919).

\footnotetext{
* Present address: Department of Botany and Plant Pathology, Oregon State University, Corvallis, Oregon 97331, U.S.A.
} 
Type cultures of Microbacterium flavum

The American Type Culture Collection (ATCC) organism no. I0340 is a 'co-type' of Microbacterium flavum, reputed to be that of Orla-Jensen (1919) (Sneath \& Skerman, I966). A second culture of it is held in the NCIB as strain 8707 and was deposited by Dr Doetsch who obtained it from Orla-Jensen. This organism was described by Doetsch \& Pelczar (1948) but it does not conform to the original description of Microbacterium flavum given by Orla-Jensen (1919). The Microbacterium flavum of Orla-Jensen (1919) and the Microbacterium flavum of Doetsch \& Pelczar (1948) are two different organisms (Buchanan et al. 1966; personal communication from $\mathrm{Mr} \mathrm{A}$. R. MacKenzie of the NCIB). The original strain of Microbacterium flavum Orla-Jensen, I9I9 has apparently been lost.

In the absence of any better alternative, we obtained NCIB 8707, the Microbacterium flavum of Doetsch \& Pelczar (1948); extensive taxonomic tests of this strain have been reported by Robinson (1966a,b), who suggested the species should be allotted to the genus Corynebacterium. Jensen (1952, 1966) suggested all the microbacteria should be classified in Corynebacterium.

\section{Tests on Microbacterium flavum (NCIB 8707)}

Morphology. We agree with Robinson's (1966a) description of the cellular and colony morphology. Colony morphology on nutrient agar was indistinguishable from Mycobacterium flavum 301.

Growth on various media. Microbacterium flavum utilized glucose and fructose (Robinson, 1966a); Mycobacterium flavum $30 \mathrm{I}$ did not (Federov \& Kalininskaya, 1961 $a, b)$. Microbacterium flavum did not grow on Kalininskaya's low nitrogen medium (see Biggins \& Postgate, 1969) with either lactate or glucose as carbon source, nor did it grow on Kalininskaya's medium with lactate + I g. $\left(\mathrm{NH}_{4}\right)_{2} \mathrm{SO}_{4} /$ l. It grew well on such media supplemented with $2 \mathrm{~g}$. yeast extract/1. in accord with Robinson's (1966a) report that Microbacterium flavum did not use inorganic nitrogen compounds.

Tests for acetylene reduction. Actively growing cultures of Microbacterium flavum in nutrient broth, dextrose peptone broth or Kalininskaya's medium $(+2 \mathrm{~g}$. yeast extract/1. with either lactate or glucose) produced no ethylene over $3 \mathrm{~h}$. at $30^{\circ}$ when tested as was Mycobacterium flavum 30 I (Biggins \& Postgate, I969) under Ar +0.04 atm. $\mathrm{C}_{2} \mathrm{H}_{2}$ with and without 0.05 atm. $\mathrm{O}_{2}$.

Serology. Broken suspensions of Microbacterium flavum gave no reaction on Ouchterlony (I949) plates against antiserum to Mycobacterium flavum 30I prepared according to Coombs \& Gell (1963); broken suspensions of Mycobacterium flavum 301 gave six precipitation lines.

\section{Comparison of Mycobacterium flavum 301 with Corynebacterium equi}

Federov \& Kalininskaya (I96r $a$ ), classifying strain 30I according to an edition of Bergey's Manual, considered it to be 'closely related to the species Corynebacterium equi'. Some strains of $C$. equi may be quite strongly acid-fast and Jensen (1952) stated that 'this species might probably with as much right be placed in Mycobacterium'. We obtained C. equi (National Collection of Type Cultures (NCTC) I62I); its cells were dumpy, almost coccoidal, rods, shorter and thicker than Mycobacterium flavum 30r; 
they did not have the swollen ends typical of the latter. Corynebacterium equi grew rapidly on nutrient agar ( $\mathrm{I}$ to $2 \mathrm{~mm}$. diam. colonies in $24 \mathrm{~h}$.) to produce white colonies. Suspensions of broken $C$. equi showed no reaction with antiserum to Mycobacterium flavum $30 \mathrm{I}$ on Ouchterlony plates.

\section{Suggested relation of Mycobacterium flavum 301 to Arthrobacter}

Jensen (1965) suggested that Mycobacterium flavum 30r ' was apparently more like an Arthrobacter species', but gave no reasons for this assertion. According to Jensen (1952), mycobacteria evolved from Arthrobacter-like organisms. In Masuo \& Nakagawa's (1969) survey, several Arthrobacter strains clustered at a high similarity level with species of Mycobacterium; other surveys have emphasized the mixture of organisms at present classified in Arthrobacter (Da Silva \& Holt, 1965; Davies \& Newton, 1969). Dr M. Tsukamura (personal communication) reported that Mycobacterium flavum 30 I had a greater tendency to filament formation than seven representative strains of Arthrobacter.

\section{Comparison of Mycobacterium flavum $30 \mathrm{r}$ with Nocardia}

Morphology is a basic taxonomic character in corynebacteria though it is difficult to use because gradual transitions exist between species (e.g. the CorynebacteriumMycobacterium-Nocardia complex) and because it varies with growth conditions. Morphologically, Mycobacterium flavum $30 \mathrm{I}$ appeared rather like a Nocardia; it tended to develop filamentous and occasionally rudimentary branched forms. However, it characteristically developed mycelial forms late in the growth phase, whereas Nocardia generally show mycelia early in the growth phase and fragment only later.

Nocardia calcarea NCIB 8863 and Nocardia cellulans NCIB 8868 were chosen for comparison because nitrogen-fixing ability had been claimed for these species (Metcalfe \& Brown, 1957) though in this laboratory the type cultures failed to fix nitrogen (Hill \& Postgate, 1969). They also showed smooth, wet-type colony morphology, unlike most nocardias (Tsukamura, 1969) but like Mycobacterium flavum 30I. They had a similar morphology to $M$. flavum $30 \mathrm{I}$, including a tendency to form terminal granules and swollen ends, and were of similar dimensions in shake-flask cultures on nutrient broth except that $N$. cellulans was usually about $50 \%$ longer. Broken suspensions and crude supernatant extracts $(38,000 \mathrm{~g}$ for $30 \mathrm{~min}$.) of each Nocardia species did not produce any precipitation lines with antiserum to $M$. flavum $30 \mathrm{I}$ on Ouchterlony plates. Hill \& Postgate (I969) reported that they did not reduce acetylene, even in media appropriate to $M$. flavum 301 .

Mycobacterium flavum 30I showed some arylsulphatase activity which most Nocardia do not (Tsukamura, 1969), but only after prolonged (2 weeks) incubation. Unlike most rapidly growing mycobacteria (Tsukamura, 1966), strain 301 did not tolerate $0.2 \%$ picric acid on Sauton's (I9I2) agar; it did not utilize mannose as sole carbon source, nor did it form acid from it. Mycobacterium flavum $30 \mathrm{I}$ was only partially acid-fast. Mycobacteria are usually more strongly acid-fast than Nocardia but acidfastness is not a reliable taxonomic character (Jensen, I952, I966; Gordon, 1966); it varies with medium and staining treatment (Harrington, 1966). 


\section{Some relevant properties of Mycobacterium flavum $30 \mathrm{I}$}

Gram reaction. We could not confirm the report of the discoverers that the organism was Gram-negative. In our hands it was Gram-positive from nutrient agar; organisms from Kalininskaya's nitrogen-free medium with lactate stained weakly but Gram-positive with only occasional Gram-negative organisms.

DNA base composition. Measurements of the melting point $\left(T_{m}\right)$ of purified DNA, kindly performed at the National Collection of Industrial Bacteria, indicated $69 \%$ guanine + cytosine. This falls within the range quoted by Hill(I966) for Mycobacterium (64 to $70 \%$ ) or Nocardia (64 to $72 \%$ ) but outside Arthrobacter (60 to $64 \%$ ) and Corynebacterium ( $48 ; 5 \mathrm{I} \cdot 5$ to $59 \%$; Corynebacterium equi $=58.5 \%$ ).

Mycobactin formation. No mycobactin (see Snow, 1970) was detected by Dr C. Ratledge in $0.69 \mathrm{~g}$. dry wt organism grown in an iron-deficient variant of Kalininskaya's medium with lactate $+\mathrm{I}$ g. $\mathrm{NH}_{4} \mathrm{Cl}$ and $0 \cdot 2 \mathrm{~g}$. yeast extract/l.

Heat resistance. Microbacteria are notably heat-resistant, though Microbacterium flavum is less resistant than other species in the genus, surviving $60^{\circ}$ but not $65^{\circ}$ for Io min. (Robinson, 1966a). Mycobacterium flavum $30 \mathrm{I}$ grown on Kalininskaya's medium with lactate, tested for heat resistance using Robinson's conditions, survived $55^{\circ}$ but not $60^{\circ}$ for $10 \mathrm{~min}$.

\section{DISCUSSION}

The taxonomic status of Mycobacterium flavum $30 \mathrm{I}$ is of importance when considering the distribution of nitrogen fixation among bacteria. In Bergey's schemes it might belong in the genera Microbacterium, Corynebacterium, Nocardia, Arthrobacter or Mycobacterium. Our experiments do not provide an unequivocal placing for the organism, chiefly because of the generally unsatisfactory nature of the taxonomy of the coryneform bacteria (Jensen, I952, I966), but also because Microbacterium flavum (NCIB 8707) appears not to be a co-type of Orla-Jensen's organism. However, Mycobacterium flavum $30 \mathrm{I}$ corresponds neither to NCIB 8707 nor to Orla-Jensen's original description. The DNA base ratio tends to restrict it to Nocardia or Mycobacterium; the absence of mycobactin in conditions in which it would readily be detected in normal mycobacteria argues against it being in the latter genus. Our experiments suggest that it is closest to Nocardia, which would be consistent with Metcalfe \& Brown's (1957) report of nitrogen fixation in that genus, even though the type strains no longer fix nitrogen. Our findings emphasize the need to reclassify Mycobacterium flavum 301 according to Bergey's taxonomy and we recommend that it be included in any future taxonomic surveys of the coryneform bacteria.

We are grateful to Dr M. Tsukamura, Chuba Chest Hospital, Aichi, Japan, and to Dr C. Ratledge, Department of Biochemistry, University of Hull, for examining Mycobacterium flavum $30 \mathrm{I}$ and for commenting on this manuscript.

\section{REFERENCES}

Biggins, D. R. \& Postgate, J. R. (1969). Nitrogen fixation by cultures and cell-free extracts of Mycobacterium flavum 301. Journal of General Microbiology 56, I8I-193.

Breed, R. S., Murray, E. G. D. \& Hitchins, A. P. (I948). Bergey's Manual of Determinative Bacteriology, 6th edn. Baltimore, Maryland: The Williams \& Wilkins Co. 
BreEd, R. S., Murray, E. G. D. \& SMIth, N. R. (1957). Bergey's Manual of Determinative Bacterio$\log y, 7$ th edn. Baltimore, Maryland: The Williams \& Wilkins Co.

Buchanan, R. E., Holt, J. G. \& Lessel, E. J. Jun. (1966). Index Bergeyana. Edinburgh: E. \& S. Livingstone.

CoomBs, R. R. A. \& Gell, P. G. H. (1963). In Clinical Aspects of Immunology, p. I. Edited by P. G. H. Gell \& R. R. A. Coombs. Oxford: Blackwell.

DA Silva, G. A. N. \& Holt, J. G. (1965). Numerical taxonomy of certain coryneform bacteria. Journal of Bacteriology 90, $921-927$.

Davies, G. H. G. \& Newton, K. G. (I969). Numerical taxonomy of some named coryneform bacteria. Journal of General Microbiology 56, 195-214.

Doetsch, R. N. \& Pelczar, M. J. (1948). The microbacteria. I. Morphological and physiological characteristics. Journal of Bacteriology 56, 37-49.

Federov, M. N. \& KALININSKAYA, T. A. (196I $a$ ). A new species of nitrogen-fixing Mycobacterium and its physiological properties. Mikrobiologiya 30, 9-14.

Federov, M. V..\& KalininsKaYA, T. A. (196I $b$ ). The relation of the nitrogen-fixing Mycobacterium (Mycobacterium sp. 30I) to various carbon sources and to additional growth factors. Mikrobiologiya 30, 833-840.

GoRDON, R. E. (1966). Some strains in search of a genus-Corynebacterium, Mycobacterium, Nocardia or what? Journal of General Microbiology 45, 329-343.

HARRINGTON, B. J. (1966). A numerical taxonomic study of some corynebacteria and related organisms. Journal of General Microbiology 45, 31-40.

HILL, L. R. (1966). An index to deoxyribonucleic acid base compositions of bacterial species. Journal of General Microbiology 44, 419-438.

Hitl, S. \& Postgate, J. R. (1969). Failure of putative nitrogen-fixing bacteria to fix nitrogen. Journal of General Microbiology 58, 277-285.

Jensen, K. L. (1934). Studies on saprophytic mycobacteria and corynebacteria. Proceedings of the Linnean Society of New South Wales 59, 19.

JENSEN, H. L. (1952). The coryneform bacteria. Annual Review of Microbiology 6, 77-90.

JENSEN, H. L. (I965). Non-symbiotic nitrogen fixation. In Soil Nitrogen, pp. 440-476. Edited by W. V. Bartholomew \& F. E. Clark. American Society of Agronomy Monograph 10.

JENSEN, H. L. (1966). Some introductory remarks on the coryneform bacteria. Journal of Applied Bacteriology 29, I3-16.

Krasil'NIKov, N. A. (1959). Diagnostik der Bakterien und Actinomyceten. Jena: VEB Gustav Fischer Verlag. (German translation of 1949 Russian edition.)

Masuo, E. \& NaKagaWA, T. (1969). Numerical classification of bacteria. Part II. Computer analysis of 'coryneform bacteria' (2). Comparison of group formations obtained on two different methods of scoring data. Agricultural and Biological Chemistry 33, II $24-1133$.

Metcalfe, G. \& Brown, M. E. (1957). Nitrogen fixation by a new species of Nocardia. Journal of General Microbiology $17,567-572$.

OrLa-Jensen, S. (1919). The Lactic Acid Bacteria. Copenhagen.

OUChTERLONY, O. (1949). Antigen-antibody reactions in gels. Acta pathologica et microbiologica scandinavica 26, 507-515.

Robinson, K. (1966a). Some observations on the taxonomy of the genus Microbacterium. I. Cultural and physiological reactions and heat resistance. Journal of Applied Bacteriology 29, 607-61 5 .

RoBINson, K. (1966b). Some observations on the taxonomy of the genus Microbacterium. II. Cell wall analysis, gel electrophoresis and serology. Journal of Applied Bacteriology 29, 616-624.

SAUtON, B. (1912). Sur la nutrition minérale du bacille tuberculeux. Compte rendu hebdomadaire des séances de l'Academie des sciences 155, 860-86r.

SNEATH, P. H. A. \& SkERMAN, B. V. D. (1966). A new list of type reference strains of bacteria. International Journal of Systematic Bacteriology 16, I-133.

SNow, G. A. (1970). Mycobactins: iron-chelating growth factors from mycobacteria. Bacteriological Reviews 34, 99-125.

TsukAmura, M. (1966). Adansonian classification of mycobacteria. Journal of General Microbiology 45, $253^{-273 .}$

Tsukamura, M. (1969). Numerical taxonomy of the genus Nocardia. Journal of General Microbiology 56, 265-287. 